\title{
THE USE OF BLENDED LEARNING IN TEACHING READING
}

\author{
I Made Yudik Wirawan ${ }^{1}$, Putu Enik Kristiani ${ }^{2}$ \\ ${ }^{1,2}$ Universitas Pendidikan Ganesha \\ Email: yudikwirawan07@gmail.com
}

\begin{abstract}
The advancement of technology, communication, and data, particularly the internet, has attracted the attention of Indonesian educators who want to use it as a source of positive learning media to support in the teaching and learning process. This study aims to know the advantages of use of Blended learning in English teaching reading skills. This literature study reviews some papers in studying the use of Blended learning and its advantages. The findings of this study showed blended learning provides many sources for the teacher and students to get the reading materials. Due to the multi-sources in blended learning, it helps the students to develop their daily reading activity. The Blended Learning can make students become active learners because the students can get the other additional information from the internet during the online learning it is effective to make the students enjoy the learning process and do not feel bored with the monotonous learning situation. And also, the virtual class has easy access anywhere and anytime in different places at the same time and also makes it easier for teachers to create archives in digital form. The findings indicated that there are some models of blended learning that can be implemented based on the situation and the condition of the learning process. Thus, this study can provide teachers with information about using Blended Learning as an approach in teaching-learning activities that will benefit both students and teachers in facilitating the teaching-learning process of reading.
\end{abstract}

Keywords: Blended learning, reading, teaching

(c) (1) This work is licensed under Creative Commons Attribution License 4.0 CC-BY International license

\section{INTRODUCTION}

\subsection{Introduction}

Learning systems around the 21st Century experienced a change caused by the demands of the era from year to year and the center of the learning system changed which was initially centered on the teacher moved more student-centered (Ichsan et al., 2019). Education 4.0 is an answer to the industry revolution (IR4.0) requires where humans and technology converge to allow for new possibilities (Hussin, 2018). According to Fisk as cited in Hussin (2018), the new learning vision enables learners not only to learn the necessary skills and knowledge but also to recognize the source through learning certain skills and knowledge. Industry 4.0 is a new 
generation from a revolution in the past which revolution affects the technical sectors including the field of education. The higher learning institution is seen as the forum for improving the skills that are necessary for Industry 4.0 adoption.

Reading is one of the language skills acquired through the process of language learning (Delfi, 2017). Nowadays, reading is one of the basic skills that must be possessed by individuals. The ability to read becomes important in a society because through reading it can be absorbed by various information and knowledge insights to develop the civilization of the community. However, there are many students who still lack literacy. Teaching reading needs to get a very important position, however, it is unfortunate that not all parties realize the importance of reading. Especially in Indonesia, they only get language learning in the context of school which students learn languages only to meet the demands of the curriculum. Reading is an important skill that teachers and students must deal with on a regular basis in the classroom, (Masduqi, 2014). Indonesia is a country that English as a foreign language has limited time in the context of learning in the classroom. Because of the limited teaching time in the classroom, the teacher can provide an online learning model to increase student ability in reading skills.

Blended learning is a teaching method that mixes classical face-to-face classroom sessions with activities conducted outside of the classroom, most of which make use of internet resources, (Djiwandono, 2018). The use of Information and Communication Technology (ICT) in sustaining the learning process is very helpful for students and teachers. Through ICT students can access material independently through the internet. Blended learning creates a way to focus on individual student's strengths, weaknesses, learning needs, and matching students with the right personalized content at the right time (Schechter et al., 2015). The progression of innovation, correspondence, and data, especially the web, has made it an unquestionable requirement for Indonesian educators to have the option to utilize it as a wellspring of positive learning media to help instructing and learning, (Zainuddin \& Keumala, 2018).

This is a transition from passive learning to active learning which there are two problems in applying the importance of employing technology for teaching. In line with the uses of technology developed to facilitate teaching and learning of reading skills, most teachers only teach the students in the classroom contexts, and the teachers also only use paper-based teaching and learning activities in delivering material without using the internet as one of the technologies widely used to develop their teaching media. Not only the teacher factor, most students often do not use technology for the academic purpose, and also it is in line with Sari, 2019) the understudies would prefer not to adapt autonomously in light of the fact that the social and social factors that acclimate them to learning are constantly directed and provided guidance, and the absence of excitement of understudies who would prefer not to face challenges or participate in exercises outside their comfort zone.

Kofar (2016) conducted research entitled "A Study of EFL Instructors' Perceptions of Blended Learning". The results show that the teacher has positive perceptions of Blended teaching strategies, although they face a number of difficulties with regards to the implementation. In this report, Turkish EFL instructors recommend teaching in a blended style, suggesting the possible success that may come with the use of a blended learning method. As long as teachers are provided with the preparation that can cast doubt on the efficient and proper 
implementation of blended learning, teachers will be well prepared to handle their time effectively.

Besides that, Djiwandono (2018), a study was done in which participants were divided into two groups: control, and experimental. The control group was taught with mixed learning over a period of 6 weeks wherein face-to-face sessions were held variously with online sessions. Meanwhile, the experimental group just had face-to-face sessions. The findings revealed that the control group raised their reading abilities and vocabulary mastery significantly, due to the fact that the online sessions provided them with more exposure to various reading texts, which in turn improved their vocabulary proficiency. The teacher should teach the students strategies to read efficiently in face-to-face sessions. Online sessions can follow this where learners can deal with more varied texts that they understand using the strategies previously learned during face-to-face sessions.

It can be seen that the previous studies showed that blended learning is needed to be used in teaching reading. Therefore, considering to the importance of teaching reading and the benefits of using blended learning, this study aimed at investigating how blended learning can be used in teaching and learning process to teach reading skill. Through the results of this study, the teachers are expected to receive information needed about how to implement blended learning in their teaching and learning process.

\section{METHOD}

Literature study was used as the method of this study in collecting the data. The purpose of literature study is to provide a description of the relevant of certain topic or field by summarizing and synthesizing the arguments and ideas of others study (Ramdhani et al., 2014). There were several steps conducted by the researchers. The initial stage was to collect the data, which was done using both primary and secondary sources. The researcher gathered data from primary sources by reading research papers on the benefit of blended learning on students' reading abilities. There were a total of six research papers that were used as the primary source. Meanwhile, the data for secondary resources came from papers and books with the total of 10 sources, which were used to support this study. Both the primary and secondary sources were gathered online through credible sites. The researchers classified the data relevant to the use of blended learning in teaching reading skills in the second step. The data had to be analyzed next. After reviewing the data, the researcher went on to the next phase, which was to develop a conclusion based on the findings. Generally, the goal of this study is to determine the benefits of using Blended Learning in teaching reading.

\section{FINDINGS AND DISCUSSION}

\subsection{Findings}

Blended learning is the process of combining two or more types of learning which between synchronous learning or face-to-face learning and asynchronous learning by using textbased internet learning, (Garrison and Kanuka, 2004, p.96). Another definition of blended learning also conveys by Karkour (2014), that blended learning is the teaching strategy which combine two mode of learning namely face-to-face learning in the classroom and the online learning or internet-based learning. In line with those two definitions of blended learning, 
Ghazizadeh and Fatemipour (2017) also define blended learning as the mixed modes of teaching in which teacher and students are conducted learning and assessment activity in the real classroom and the technology mediated. In the other words, blended learning is the teaching and learning activity that is conducted in the classical classroom and online classroom.

Blended learning is a beneficial learning model in teaching and learning language. Keshta and Harb (2013) believes that blended learning is important in developing students' reading skill because blended learning provides many sources for the teacher and students to get the reading materials. Due to the multi-sources in blended learning, it helps the students to develop their daily reading activity. According to Karkour (2014), the benefits of blended learning in teaching and learning language, particularly in teaching reading are as follow:

1. Make the students become active learners. The combination between face-to-face learning and the online learning helps the students to be more active in learning. The students can get several valid information from the teachers during the face-to-face learning and get the other additional information from the internet during the online learning. Face-to-face meeting helps the students to do more interaction with the teacher and their friend, while online learning helps the students to be independent learners rather than only receive the information or the materials from the teachers and being passive learners. Moreover, online learning can help the students to get several reading materials in internet during the reading instruction.

2. Increase the students' positive attitude and motivation during the learning. The combination between face-to-face learning and online learning is effective to make enjoy the learning process and do not feel bored with the monotonous learning situation.

Furthermore, Humaira, Asbah, and Adyati (2018) state that there are several types of blended learning in teaching reading. Those types are as follow:

1. Face-to-face driver model

This type of blended learning is designed based on case-by-case, which means that only certain students will participate in the blended learning. The students that participate in this type of blended learning are the students who working on the higher level of their grade, so they are able to study based on their own speed by using technology in the classroom

2. Rotation model

This type of blended learning allows students to do both mode of learning namely face-to-face learning and online learning alternately according to the specified schedule. This type is mostly applied in California, particularly in the elementary school.

3. Flex model

This type of blended learning is the combination of both face-to-face and online learning at the same time. It means that the teacher and students are in the classroom but the material is provided in the online platform. The existence of the teacher in the classroom is to support the students when they need guidance. Meanwhile, the students learn the material independently through the technology in the classroom. In other words, the students conduct independent learning and monitor by the teacher.

4. Online lab model

This type of blended learning is conducted by using the school computer lab during the learning activity. The students are allowed to work based on their own pace to complete the assignment or coursework without disturbing the other students' pace.

5. Self-blend model

This type of blended learning allows students to take other classes beside their classes in school. They can take the traditional class and also online class individually. 


\section{Online driver model}

This type of blended learning is conducted by providing the material through online learning and allows the students to do online discussion with the teacher when they have questions related to the material. Meanwhile, the traditional classroom in optional. This type of online learning provides the flexibility for the students based on their daily schedule.

\subsection{Discussion}

There were many researchers who conducted similar and related studies with this research in which they might use the same theories or concepts with this research. A study by Zainuddin and Keumala (2018) indicated that technology can be one of the best solutions in facilitating communication between the teacher and the students in blended learning. The statement from Fisher as cited in Zainuddin \& Keumala (2018) also indicates that in helping communication between teacher and students in blended learning, technology can be used in an alternative way. The other researcher also stated that in learning English, technology is very helpful along with the development of science and technology (Sari, 2019). Not only the technology factor, according to Trapp (2006), students' contributions greatly affect the success and effectiveness of the learning process. And also in implement the blended learning the role of higher education institutions is vital in preparing infrastructure in improving teaching and learning processes along with the high need for technology use in education (Bataineh \& Mayyas, 2017).

In the context of teaching reading, blended learning are reported to bring positive contributions to the students. A study by Alnuari (2018) found that the use of blended learning could be beneficial for the students. The students were reported to actively participate during the learning process, whereas they could answer and being involved in the question and answer session. Besides, the use of blended learning was also found to be useful as the students were exposed more to the use of technology. The study by Alnuari (2018) was conducted as an experimental study which divided the students into two groups, which were experimental and control group. The experimental group was given treatment with blended learning for six weeks, before finally tested through reading comprehension test. It was revealed that the study was conducted by using the flex model, as suggested by Humaira, Asbah, and Adyati (2018). Through the model, the face-to-face and online learning were conducted at the same time, whereas the teacher and the students were both studying in the classroom but the materials were accessed online. The materials that were being accessed were in the form of online stories, worksheet, and videos. Since the blended learning provided many selection of materials, the study also reported that it was also beneficial to avoid the students from being bored while studying in the classroom. Thus, the use of flex blended learning model can be more beneficial in the context of face-to-face teaching and learning process.

The use of flex blended learning model is also reported to bring good cause through the study conducted by Ang and Yunus (2018). The study arose due to the worries that students, particularly children were no longer interested in reading books. This was an irony as the government had sponsored the printing of textbooks for public schools only for the students to neglect them. Thus, through this study that was conducted in Malaysia, the researchers found that the use of blended learning in the flex model can be very beneficial to encourage and 
promote reading to the students, especially young learners. The study implemented flex blended learning model whereas the teachers and the students were still meeting in the classroom. However, the learning and reading materials were collected and presented online. The materials accessed online provide students with the visual aids, such as pictures, videos, and projectors that are of their interests and thus encourage them more to study (Yunus et al., 2013). This can be helpful because as suggested by Bhatti (2016), textbooks have limitation in providing the students with the correct pronunciation and context meaning of the words they are reading. Thus, the visual and audio provided through the use of blended learning can be a great help. Besides effectively teaching reading, the use of blended learning can also maximize the use of the textbook together with the ICT.

More study also proved the effectiveness and advantages of using blended learning in Flex model. Study by Humaira and Asbah (2019) also used flex model in the implementation of blended learning in their quasi-experimental research. The teachers and the students were still meeting face-to-face as usual. However, they were given reading materials in the form of stories which were accessed online. A reading comprehension test was conducted after the treatment. Similar to the results of the previous studies, the result of this study indicated that the students who got blended learning performed better by achieving higher scores in the reading test compared to the control group. This further emphasizes the benefits of using blended learning, particularly the flex model in teaching reading as suggested by the prior studies.

Besides flex blended learning model, another study also implemented other types of blended learning. A study by Lukitasari et al., (2019) implemented online driver blended learning model in teaching reading. The online driver blended learning model, as suggested by Humaira, Asbah, and Adyati (2018), is conducted by allowing students to have online discussion with the teachers when they have difficulties in learning, which provides flexibility for the students. To achieve this, the study by Lukitasari et al., (2019) implemented the blended learning by using Edmodo, an online learning management system. Edmodo was chosen as the platform has several features that can support the implementation of the blended learning model. The features include groups, calendar, notes or alerts, assignment, quizzes, library, and grade books. The teachers can post reading materials and assignment following them. On the other hand, the students can access them online and ask the teacher whenever they feel confused. This way, the students can be provided with flexible, fun learning materials and methods while also be encouraged to read more.

Even though the use of flex blended learning and online driver blended learning models seem promising, the current situation with the pandemic of COVID-19 certainly limits the implementation of blended learning. Therefore, a more in-depth and strategic implementation is needed in order to best teach reading during the pandemic. A study by Setyowati et al., (2021) provided the examples of how blended learning can still be optimally used during the pandemic. Setyowati et al., (2021) state that the teaching and learning process needed to be divided into three different parts, which were pre-activity, whilst activity, and post-activity with the use of several learning platforms. In this study, reading was integrated with other skill, which was writing. The reading activity was conducted in the pre-activity.

In the pre-activity, the teacher delivers the learning objectives and check the students' attendance through the use of Google Form. The teacher then does brainstorming or warming up 
by introducing and encouraging the students to dig further about the topic that would be discussed. Then, a reading text related to the topic can be given through Google Classroom, Telegram Group, or WhatsApp group. In this session, it is important to have clear and exact duration of time for the students to read (Setyowati et al., 2021). This way, the students will have time to read and explore the topics while the teacher can confirm that the students really are reading. Then, in whilst activity phase, the teacher can proceed to ask the students to start writing about the topics. Finally, in the post-activity, the students can be asked to present their work through the use of video conference platforms, such as Zoom and Google Meet, so that everyone in the class can watch. This procedure is more appropriate for students in higher grade as they already possess self-governance to responsibly study and complete their tasks.

Studies by Kaur (2013), Karkour (2014), and Komang et al., (2014) provide more insights about the benefits that can be obtained from online learning, especially when being used to teach reading. Blended learning provides many options for delivery methods, learning models and learning styles without reducing the interactive process (Kaur, 2013). According to Kaur (2013), the virtual class has easy access anywhere and anytime in different places at the same time and also makes it easier for teachers to create archives in digital form. Online class sessions help to provide wider space in supporting deficiencies in conducting conventional classes (Djiwandono, 2018). The benefits of blended learning compared to traditional learning easily adapted to the needs of students and trains students to learn independently so that the burden of the teacher can also be alleviated (Sari, 2019).

However, apart from the benefits that have been mentioned, the implementation of blended learning also has several challenges. The challenges in implement of Blended learning are the use of technology as an educational and effective media and the lack of awareness and understanding in the use of technology (Zainuddin \& Keumala, 2018). Besides that, according to Heinze and Procter as cited in Lamri \& Hamzaoui (2018), in conducted blended learning the amount of time spent and the type of technology also affects the quality produced. The challenges of Blended learning in transforming higher education is the rapid development of innovative technology in traditional learning environments (Marunić \& Glažar, 2015). According to Futch as cited in Gedik (2012), the biggest challenges for students in implementing blended learning are time management, learning designs that are not suitable and the family economy.

Nevertheless, apart from the weaknesses, the use of blended learning is still proved to be beneficial in the process of teaching English, particularly reading skill. As there are many models of blended learning, as suggested by Humaira, Asbah, and Adyati (2018), it then becomes the task of the teacher to decide the type that would best suit the condition and situation of the students and the learning process. Thus, the best learning environment can be created in complement to the learning method being chosen. This is done in order to successfully get the benefits that are offered by blended learning.

\section{CONCLUSIONS}

\subsection{Conclusion}

This research aimed to investigate the ways blended learning can be used to teach reading skills. The results indicated that there were many models of blended learning that could be implemented by the teachers, which were adapted based on the condition and situation of 
learning as well as the students' needs. The results also indicated that blended learning provided many sources for the teacher and students to get the reading materials. Due to the multi-sources in blended learning, it helps the students to develop their daily reading activity. The Blended Learning teaching strategy can make students become active learners because the students can get the other additional information from the internet during the online learning. Blended Learning teaching strategy provided face-to-face learning and online learning is effective to make the students enjoy the learning process and do not feel bored with the monotonous learning situation. However, even though the use of blended learning is good but in the transition from passive learning to active learning which there are still found a problem in applying the blended learning such as the facilitate in teaching and learning process.

\subsection{Suggestions}

As this study only provided several ways of implementing blended learning models, further research is suggested for other researchers. More exploration on blended learning implementations and models are highly suggested. Further, as the teachers are the ones who will be fully responsible in deciding the models of blended learning that will be implemented, it is suggested that besides having the implementations on this study as a reference, the teachers need to explore more on the implementation.

\section{REFERENCES}

Ang, T., \& Yunus, M. M. (2018). Blended Learning: To Read or Not To Read. IJIE (Indonesian Journal of Informatics Education), 2(1), 29. https://doi.org/10.20961/ijie.v2i1.20348

Bataineh, R. F., \& Mayyas, M. B. (2017). The utility of blended learning in EFL reading and grammar: A case for moodle. Teaching English with Technology, 17(3), 35-49.

Bhatti, M. S. (2016). Investigating The Condition of Teaching Reading Skill at Secondary Level. Proceedings of 2nd International Multi-Disciplinary ..., December.

https://www.academia.edu/download/51526767/Investigating_The_Condition_of_Teaching _Reading_Skill_at_Secondary_Level.pdf

Delfi, S. (2017). an Analysis of Studies on Teaching and Learning. Journal of English for Academic, 4, 101-115.

Djiwandono, P. I. (2018). The Effect of Blended Learning on Reading Abilities, Vocabulary Mastery, and Collaboration among University Students. January.

Gedik, N. (2012). The Optimum Blend: Affordances and Challenges of Blended Learning For Students. Turkish Online Journal of Qualitative Inquiry, 3(3), 102-117. https://doi.org/10.17569/tojqi.82614

Humaira, H., \& Asbah, A. (2019). Investigating the Effect of Blended Learning Activity in Teaching Reading at Second Grade Senior High School. Linguistics and Elt Journal, 6(1), 30. https://doi.org/10.31764/leltj.v11i1.745

Hussin, A. A. (2018). Education 4 . 0 Made Simple : Ideas For Teaching. International Journal of Education and Literacy Studies, 6(3), 92-98.

Ichsan, I. Z., Sigit, D. V., Miarsyah, M., Ali, A., Arif, W. P., \& Prayitno, T. A. (2019). HOTS- 
AEP: Higher order thinking skills from elementary to master students in environmental learning. European Journal of Educational Research, 8(4), 935-942.

https://doi.org/10.12973/eu-jer.8.4.935

Karkour, I. (2014). A blended learning model for teaching reading in english as a foreign language. Teaching English with Technology, 14(4), 17-31.

Kaur, M. (2013). Blended learning - its challenges and future. Procedia - Social and Behavioral Sciences, 93, 612-617. https://doi.org/10.1016/j.sbspro.2013.09.248

Komang, M., Nitiasih P K, \& Budasi, I. G. (2014). Developing Blended Learning Based Reading Materials for the Tenth Grade Multimedia Students of Smk Wira Harapan. Jurnal Program Pascasarjana Universitas Pendidikan Ganesha, 2, 1. https://doi.org/10.4304/jltr.4.2.301309

Kofar, G. (2016). A Study of EFL Instructors $\square$ Perceptions of Blended Learning. Procedia Social and Behavioral Sciences, 232(April), 736-744.

https://doi.org/10.1016/j.sbspro.2016.10.100

Lamri, C. E., \& Hamzaoui, H. (2018). Developing ELP students' reading skills through a blended learning approach. Eurasian Journal of Applied Linguistics, 4(2), 389-407. https://doi.org/10.32601/ejal.464204

Lukitasari, D. R., F, V. A., \& Gloria, E. (2019). The Use of Edmodo for Teaching Reading in a Blended-Learning Classroom. Indonesian Journal of English Language Studies, 5(2). https://e-journal.usd.ac.id/index.php/IJELS/article/view/2864/pdf

Marunić, G., \& Glažar, V. (2015). Challenges of blended learning. Scientific Proceedings Xxiii International Scientific-Technical Conference, 3, 61-64.

Masduqi, H. (2014). Efl Reading in Indonesian Universities: Perspectives and Challenges in Cultural Contexts. Journal of Teaching and Education, 03(03), 2165-6266.

Sari, I. (2019). Students 'Perception on the Effective ness of Blended Learning : Efforts in the Mastery of English. International Journal of Research and Review, 6(February), 259-265.

Schechter, R., Macaruso, P., Kazakoff, E. R., \& Brooke, E. (2015). Exploration of a Blended Learning Approach to Reading Instruction for Low SES Students in Early Elementary Grades. Computers in the Schools, 32(3-4), 183-200.

https://doi.org/10.1080/07380569.2015.1100652

Setyowati, L., Sukmawan, S., \& El-Sulukkiyah, A. A. (2021). Learning from home during pandemic: A blended learning for reading to write activity in EFL setting. JEES (Journal of English Educators Society), 6(1), 9-17. https://doi.org/10.21070/jees.v6i1.662

Trapp, S. (2006). Blended learning concepts - A short overview. CEUR Workshop Proceedings, $213,28-35$.

Yunus, M. M., Salehi, H., \& John, D. S. A. (2013). Using Visual Aids as a Motivational Tool in Enhancing Students Interest in Reading Literary Texts. 114-117. http://arxiv.org/abs/1305.6360

Zainuddin, Z., \& Keumala, C. M. (2018). Blended Learning Method Within Indonesian Higher Education Institutions. Jurnal Pendidikan Humaniora, 6(2), 69-77. 